\title{
The Effect of Central Bank of Nigeria (Cbn) Money Supply Management on Commercial Bank Loans and Advances (Cbla) and Output
}

\author{
${ }^{1}$ Anyanwu Uchenna, ${ }^{2}$ Kalu Alexanda O.U. \\ ${ }^{1}$ Department of Economic Faculty of Social Sciences Imo State University Owerri \\ ${ }^{2}$ Department of Marketing College of Management Sciences Michael Okpara University of Agriculture Umudike \\ Abia State
}

\begin{abstract}
Monetary policy is one of the macroeconomic instruments with which monetary authority in a country employs in the management of money supply and the economy thereof to attain the fundamental objectives of price stability and maintenance of balance of payment. The monetary policy strives to explain the correlation between macro economic variables and the monetary variable and this form the focal point of this study. The study also set out to ascertain the impact of CBN money supply on the growth of Nigeria economy, ascertain the extent of correlation that exists between money supply and output. Scholars in the field opined that contractionary monetary policy negatively influences total consumption, CBLA and output. Within this framework, money supply, CLBA and output variables are analyzed for the period of 18 years (1994-2012) using Statistical package for social sciences (SPSS) tool. The findings shows that change in money supply (M2) has significant effect on variables such as CBLA and output in Nigerian economy within the period under review, Also there is a significant strong multiple correlation among Real GDP, Money supply and Commercial Banks' loans and Advances $(R=95.1 \%)$. The coefficient of Determination (R2) reveals that $90.5 \%$ of variations in RGDP were explained by our selected explanatory variables (Money supply and Commercial Banks' loans and Advances).
\end{abstract}

\section{Introduction}

Nigeria economy is characterized is a middle income, mixed economy and emerging market with expanding financial service communications, technology and entertainment sectors. It is ranked $26^{\text {th }}$ in the world in terms of GDP (nominal: $30^{\text {th }}$ in 2013 before rebasing, 40th in 2005, 52nd in 2000), and is the largest economy in Africa (based on rebased figures announced in April 2014). It is also on track to become one of the 20 largest economies in the world by 2020.Its re-emergent, through currently under performing, manufacturing sector is the third-largest on the continent, and produces a large proportion of goods and services for the West African region. It recently changed its economic analysis to account for rapidly-growing contributors to its GDP. sure as telecommunications, banking and its film industry. In regards to the above statistical revision, Nigeria has added 89\% to its GDP, making it the largest African economy (http://economist.com/news/leaders/21600685-nigeriassuddenly-supersizedeconomy-indeed-wonder-so-are-its-still-huge? $\mathrm{Frsc}=\mathrm{dgh} 7 \mathrm{ca}$ ).

With a population of 158 million people, Nigeria is the largest in Africa and accounts for $47 \%$ of West Africa's population. It is also the biggest oil exporter in Africa, with the largest natural gas reserve in the continent. With these large reserves of human and natural resources, the country is poised to build a prosperous economy, significantly reduced poverty, and provides health and education and infrastructural services to meet its population need. Oil-rich Nigeria has been hobbled by price instability, political instability, corruption, inadequate infrastructure and poor macroeconomics management (index, 2013).

Monetary policy is among the macroeconomic instruments with which the monetary authority of a country controls the supply of money, often targeting a rate of interest for the purpose promoting economic growth and stability. The prime purpose of implementing monetary policy usually includes relatively stable price, high Real GDP and low unemployment (FRB, 2006). Also it is the actions of a Central Bank, Currency Board or other regulatory committee that determines the size and rate of growth of the money supply, which in turn affects interest rates. Monetary policy is maintained through measures such as increasing or reducing the interest, or changing the amount of money banks need to keep in their vault (Bank reserves) (Investopedia, 2014).

The conduct of monetary policy in Nigeria and activities of the central Bank of Nigeria relate with the core mandate of the bank and therefore are best understood from this perspective. Consequently, in pursuance of its functions in compliance with the core mandate, the CBN undertakes monetary policy in order to:

* Maintain Nigeria's external reserves to safeguard the international value of the legal currency.

* Promotion and maintenance of monetary stability and a sound and efficient financial system in Nigeria. 
Act as Banks banker

* Act as Banker and financial adviser to the Federal Government and

* Act as lender of last resort to banks.

Furthermore, monetary policy is the macroeconomic policy laid down by the Central Bank. It involves management of money supply and interest rate and it is the demand side economic policy used by government of a country to achieve macroeconomic objectives like employment, inflation, price stability, liquidity, consumption and growth. Monetary policy can be expansionary or contractionary in nature. Increasing money supply and reducing interest rate indicate an expansionary policy. The reverse of this is a contractionary monetary policy. For example, liquidity is important for an economy to spur growth. To maintain liquidity, the CBN does it through their monetary policy. By purchasing bonds through open market operations, the CBN introduces money into the system and reduces the interest rate, thereby encouraging investor to sort for credits (Economic Times, 2014).

Since the establishment of CBN in 1959, it has continued to play the traditional role expected of a Central Bank, which is to regulate the stock of money in such a way as to promote the social welfare (Ajayi, 1999).

The role of $\mathrm{CBN}$ is focused and centered on the use of monetary policy equilibrium, rapid economic growth, price stability and external balance (Fasanya, et al, 2013; Adesoye et al, 2012). Over the decades, the major goals of monetary policy have often been the two later objectives. Thus money supply, employment rate and CBLA policy have dominated CBN's monetary policy focus based on assumptions that these are essential tools of achieving macroeconomic stability (Aliyu and Englama, 2009). In order to maintain equilibrium employment rate and output and a favorable balance of payment position, monetary instruments such as total loan or CBLA, industrial production index, money supply, credit ceilings, selective credit controls, as well as the prescription of cash reserve requirements and special deposits.

In a nutshell, monetary policy refers to a combination of measures designed to regulate the value, supply and cost of money in a given economy, in consonance with the expected level of economic activity (Okwu et al, 2011; Adesoye, et al, 2012). In most of our contemporary economies, the goals of monetary policy include price stability, maintenance of balance of payments equilibrium, promotion of employment and output growth and sustainable development (Folawewo and Osinubi, 2006). These goals are necessary for the attainment of internal and external balance and the promotion of long run economic growth.

\section{Objectives Of The Study}

The main objective of this study is to ascertain the effect of CBN money supply management of CBLA and output in Nigeria Economy.

The also study set out to achieve the following sub objectives:

i. To investigate the impact of CBN money supply on the growth of Nigeria economy.

ii. To ascertain the extent of correlation that exists between money supply and output.

iii. To reveal if our model is statistically significant and if it could be used for forecasting.

\section{Statement Of Hypothese}

Ho: The effective money supply management of CBN has no positive impact on the output of Nigeria economy. Hi: The effective money supply management of $\mathrm{CBN}$ has positive impact on the output of Nigeria economy.

\section{Signicance Of The Study}

This study is relevant to policy makers since it tries to establish a link between monetary sector and the real sector. This will substantiate the theoretical framework of IS-LM equilibrium and show how activities in the monetary sector transmit to the real sector. This will guide policy makers to ensure that equilibrium is always maintained in both monetary and real sector at all time.

\section{Assumption Of The Research}

By appriori expectation, a link exists between the monetary sector policies and Real sector output. CBN management of money supply determines price level (Inflation Rate) of output and interest rate. At equilibrium between money supply and general output, a desired level signal for resource allocation, investors will invest more and expand output. Expansion of output will now add value to the total GDP.

\section{Money Supply Management}

\section{Review Of Related Literature}

The money supply or money stock is the total amount of monetary asset available in an economy at a specific time. Money supply data are recorded and published usually by government or Central Bank of the 
country. Public and private sector analyst have long monitored changes in money supply because of its effect on the price level, inflation, the exchange rate and the business circle (Taylor, 2004).

In our contemporary society, it is comparatively important to promote maximum sustainable CBLA, employment and output and promote stable prices as the fundamental goals of the monetary authority. Stability in prices and some factors which includes technology and people's preferences for saving, working and risk taking over the long run is dependent on sustainable output growth and the rate of CBLA generates (Epstein and Heintz, 2006).

Monetary policy influence the performance of the economy's crucial factors such as output, inflation and Commercial Bank Loans Advances and also prices of goods, exchange rate, consumption rate, asset prices and investment decisions. Nevertheless, the central Bank of Nigeria cannot directly control inflation or influence output and CBLA directly, it affects them indirectly by raising or lowering a short-term interest rate or by changing the money supply through an open market operations, purchasing other securities - government bonds, to increase the money supply or selling securities to decrease it (Folawewo and Osinubi, 2008).

In our contemporary society, it is comparative important to promote maximum sustainable employment and out put and to promote stable price as the fundamental goals of the monetary policy. Stability in price and some factors which includes the technology and people preferences for saving work and risk talking over the long run is dependent sustainable output growth and the number of jobs it generates (employment )(Epstein and Heitz 2006; Bernanje and Gerter, 1995).

Monetary police influence the performance of the economy crucial factors such as output inflation, and employment and also price of goods, exchange rate, consumption rate, and asset price and investment decision. never the less, the central bank of Nigeria cant not directly control inflation or influence output and employment directly, it affect them in directly by raising or lowing a short term interest rate or by changing the money supply through an open market operation; purchasing other securities government bonds - to increase the money supply or selling securities decrease it (Folawewo and Osinobi, 2006).

In this note, the monetary transmission is the process which describes how police include changes in the variable such as aggregate employment and output. Transmission channels are individually link through which monetary police impulses (O.N.B, 2011).

\section{Monetary Policy And Its Effect Impulse On Nigeria Economy}

Over the globe, each and every monetary police impulse which can be the change of interest rate or change in monetary base has a lagged impact on the economy. The credit channel is one of the real economy and it is also classified as one the non-neoclassical transmission mechanism which can arise either from government interference in markets or through imperfection in private markets (Cambazoghi and karaalp, 2012).

Monetary policy plays a significant role on employment and output. Monetary policy is the deliberate control of money supply the rate of interest by the central bank with the motive of thriving to effect a change on employment, inflation or balance of payment since capital account of payments. Also by controlling interest rate, can effect changes in the capital accounts of a country balance of payment of since relatively high rates of interest in one country will attract funds from other countries in the short form. Monetary and fiscal policies are among the approach adopted to achieve economic stabilization. Generally, money supply comprises of (a) currency in circulation and (b) demand deposit (money in current account in Nigeria therefore Include the source of money supply in Nigeria therefore include the central bank of Nigeria which issues legal tender currency (naira and kobo)and commercial banks that create dispose money.

The central bank uses number of instruments to regulate money supply in the economy .this instrument is mainly used to control the money (credit) creating powers of the commercial banks. The instruments are as follows:

\section{A. Bank Rates}

This refers to the rate of interest at which the central bank system, which will in turn, affect the rate at which the commercial banks lend too their customers. In practice we lend the bank rate is the rate at which the central bank would rediscount first class bills of exchange presented to it by the this count house. Change in this bank rate therefore effect commercial bank lending rate. An increase in the bank rate, for instance, will race the interest on loans made by commercial banks tom their customers. They will reduce borrowing and consequently money supply. On the other hands, a fall on the bank rate will reduces interest rate on loans made by commercial banks. This will encourage more customers to secure from their banks their by, increasing the amount of credit by the commercial banks.

\section{B. Special Deposits}


This deposited on at the central bank of Nigeria the commercial bank respond to a special directive which current is minimum of $25 \mathrm{bn}$. The scheme is designed to reduce bank lending in which case the bank are instructed to increase their frosts deposit if it whish to boost bank lending .

\section{Open Market Operation}

By buying or selling government securities on the open market, the central bank am vary the ability of the commercial banks to create. If , for instance it sell long term securities, he markets will be to reduce commercial bank deposit. This is because cheques will been drawn on the commercial banks in favor of the central banks by the commercial banks customers who have purchased the security .on the other hands when the central banks buy from the general public. It increases the case balance of the commercial banks by issuing out money to pay for the security purchased.

\section{Minimum Cash Ration}

Cash is the ration of a bank's case holding to it total deposit liability. It is also often referred to as inequality ration. There is a minimum level of case reserves the commercial must keep with the central banks. A change in minimum level of case reserve will affect commercial banks lending to their customers. Therefore, if the central bans raise the minimum case ration, the commercial banks will have to reduce their lending and rice versa. This is because an increase in the minimum case ration will reduce the deposit base of commercial banks and consequently their lending capacity.

\section{E) Request And Directive (Mural Suasion)}

All central banks usually have a statutory right to make request to other banks and it necessary to issue directive ensure that these are carried out. For instance, the Central Bank of Nigeria can instruct commercial banks not to lend beyond a certain amount not to lend for certain purpose consequently the CBN could advice commercial banks to allocate, say, 60 percent of their total lending of agriculture. It has also been mention earlier that monetary police can be expansion or contrationary.

Sanusi (2002) opined that the ability of the CBN to propose an effective monetary in a globalised and rapidly integrated financial market environment depends on several factors. These include: instituting appropriate legal framework, institutional structure and conducive political environment, which allows the Bank to operate with reference to excising its instrument and operational autonomy in decision- making, the degree of coordination between monetary and fiscal polices to ensure consistency and complementary; the general macrocosmic environment, including the stage of environment, depth and stability of the financial market as well as the efficiency of the payments and settlement system; the level and adequacy of information and communication facilities; and the availability of adequate, reliable, consistent, timely and high quality information to the Banks. He lay emphases that seeking a proper role for monetary policy in promoting strong and sustainable growth in a stable macroeconomic environment in Nigeria is an on-going challenge for the central bank. Furthermore, Nneka (2013) sectors in Nigeria for time frame 1986 to 2009. She noted that the main focus of monetary policy in relation to the manufacturing sector has always been the stimulation of output, employment and the promotion of domestic and external stability, while that of fiscal policy has been the generation of revenue for the government and the protection of domestic infant industries against unfair completion from import and dumping. Victor Error correction (VEC) and ordinary least square (OLS) estuations were sued to study the models for significance, magnitude, direction and relationship. The study revealed that money supply positively affected manufacturing output, index while company lending rate, company income tax rate, inflation rate, Exchange rate has a negative impact to the performance of the manufacturing sector over the years. They recommended that expansionary policies we vital for the growth of the manufacturing sector in Nigeria which in turn would lead to economic growth.

Familoni (1989) agreed that before monetary policy can produce the expected results as held by the classical economists, highly integrated and monetize economy and regular information network system are indispensable. He however lamented that Nigerian economy lacks the fundamental flexibilities (in line with interest rate, treasury Certificates etc) which could have aided a much more effective use of monetary policy. He therefore denounced the classical preference of monetary policy over fiscal policy on the basis of their empirical evidence and believed that it would only work for a developed economy and suggested, where necessary, the mixture of both policies for better performance in a developing economy like Nigeria.

\section{Regression}

\section{Data Analysis And Interpresentation}

\begin{tabular}{|l|l|l|l|}
\hline & MS & RGDP & CBLA \\
\hline 1 & 266944.90 & 275450.56 & 94183.90 \\
\hline 2 & 318763.50 & 281407.40 & 144569.60 \\
\hline 3 & 370333.50 & 293745.38 & 169437.10 \\
\hline
\end{tabular}




\begin{tabular}{|l|l|l|l|}
\hline 4 & 429731.30 & 302022.48 & 385550.50 \\
\hline 5 & 525637.80 & 310890.05 & 272895.50 \\
\hline 6 & 699733.70 & 312183.48 & 322764.90 \\
\hline 7 & 1036079.50 & 329178.74 & 508302.20 \\
\hline 8 & 1315869.10 & 356994.26 & 796164.80 \\
\hline 9 & 1599494.60 & 433203.51 & 954628.80 \\
\hline 10 & 1985191.80 & 477532.98 & 1210033.10 \\
\hline 11 & 2263587.90 & 527576.04 & 1519242.70 \\
\hline 12 & 2814846.10 & 561931.39 & 1976711.20 \\
\hline 13 & 4027901.70 & 595821.61 & 2524297.90 \\
\hline 14 & 5809826.50 & 634251.14 & 4813488.80 \\
\hline 15 & 9166835.30 & 674888.95 & 7799400.10 \\
\hline 16 & 10780627.10 & 718977.33 & 8912143.10 \\
\hline 17 & 11525530.34 & 776332.21 & 7706430.40 \\
\hline 18 & 13303494.50 & 834161.83 & 7312726.00 \\
\hline 19 & 15483847.50 & 888893.00 & 8150030.30 \\
\hline
\end{tabular}

Descriptive Statistics

\begin{tabular}{|l|l|l|c|}
\hline & Mean & Std,Deviation & N \\
\hline RGDP & 504496.9653 & 204775.1337 & 19 \\
MS & 4406540.876 & 5024821.203 & 19 \\
CBLA & 2924894.784 & 3303285.779 & 19 \\
\hline
\end{tabular}

\section{Correlations}

\begin{tabular}{|ll|c|c|c|}
\hline & RGDP & MS & CBLA \\
\hline Pearson Correlation & RGDP & 1.000 & .950 & .927 \\
& MS & .950 & 1.000 & .965 \\
& CBLA & .927 & .965 & .000 \\
\hline Sig(1-Tailed) & RGDP &. & .000 & .000 \\
& MS & .000 &. & .000 \\
& CBLA & .000 & .000 &. \\
\hline N & & & 19 \\
& RGDP & 19 & 19 & 19 \\
& MS & 19 & 19 & 19 \\
\hline
\end{tabular}

Varieables Entered /Removed ${ }^{\mathrm{a}}$

\begin{tabular}{|l|l|l|l|}
\hline Model & $\begin{array}{l}\text { Variables } \\
\text { Entered }\end{array}$ & $\begin{array}{l}\text { Variables } \\
\text { Removed }\end{array}$ & method \\
\hline 1 & CBLA,MS & & Enter \\
\hline
\end{tabular}

a. dependent Variable:RGDP

b. $\quad$ All requested Variables entered

Model Summary ${ }^{\mathbf{b}}$

\begin{tabular}{|l|l|l|l|l|l|l|l|}
\hline \multirow{2}{*}{ Model } & \multirow{2}{*}{$\mathrm{R}$} & \multirow{2}{*}{ R Square } & $\begin{array}{l}\text { Adjusted R } \\
\text { Square }\end{array}$ & $\begin{array}{l}\text { Std.Error } \\
\text { Estimate }\end{array}$ & & &
\end{tabular}

Model Summery $^{\mathrm{b}}$

\begin{tabular}{|l|l|c|c|}
\hline & \multicolumn{1}{|c|}{ Change Statistics } & & \\
Model & df2 & Sig.F Change & Durbin-Watson \\
\hline 1 & 16 & .000 & .299 \\
\hline
\end{tabular}

a. Predictors(constant),CBLA,MS

b. Dependent Variable: RGDP

ANOVA $^{\mathrm{a}}$

\begin{tabular}{|ll|l|l|l|l|l|}
\hline & Sum of Squares & & & & F & Sig \\
\hline 1. & Regression & $6.830 \mathrm{E}+11$ & 2 & $3.415 \mathrm{E}+11$ & 76.132 & .000 \\
& Residual & 71771808766 & 16 & 4485738048 & & \\
& Total & $7.548 \mathrm{E}+11$ & 18 & & & \\
\hline
\end{tabular}


a. Dependent Variable:RGDP

b. Predictors(Constant,CBLA, MS

Coefficients $^{\mathrm{a}}$

\begin{tabular}{|c|c|c|c|c|c|}
\hline \multirow[t]{2}{*}{ Model } & $\begin{array}{l}\text { Unstandardized } \\
\text { Coefficient }\end{array}$ & Std.Error & $\begin{array}{l}\text { Standardized } \\
\text { coefficient }\end{array}$ & \multirow[t]{2}{*}{$\mathrm{t}$} & \multirow[t]{2}{*}{ Sig } \\
\hline & B & & Beta & & \\
\hline $\begin{array}{ll}1 & \text { (Constant) } \\
\text { MS } \\
\text { CBLA }\end{array}$ & $\begin{array}{r}3326068.459 \\
.033 \\
.009\end{array}$ & $\begin{array}{r}20816.213 \\
.012 \\
.018\end{array}$ & $\begin{array}{l}.805 \\
.150\end{array}$ & $\begin{array}{l}15.978 \\
2.742 \\
.512\end{array}$ & $\begin{array}{l}.000 \\
.014 \\
.616\end{array}$ \\
\hline
\end{tabular}

Coefficients $^{\text {a }}$

\begin{tabular}{|c|c|c|c|c|c|}
\hline \multirow[t]{2}{*}{ Model } & \multicolumn{2}{|c|}{ 95.0\% Confidence Interval for B } & \multicolumn{3}{|c|}{ Correlations } \\
\hline & Lower Bound & Upper Bound & Zero-order & Partial & Part \\
\hline 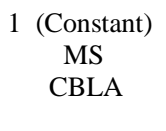 & $\begin{array}{r}288480.059 \\
.007 \\
-.029\end{array}$ & $\begin{array}{r}376736.859 \\
.058 \\
.048\end{array}$ & $\begin{array}{l}.950 \\
.927\end{array}$ & $\begin{array}{l}.565 \\
.127\end{array}$ & $\begin{array}{r}.211 \\
.039\end{array}$ \\
\hline
\end{tabular}

a. Dependent Variable: RGDP

Residuals Statistics ${ }^{\text {a }}$

\begin{tabular}{|l|l|l|c|c|c|}
\hline & Minimum & Maximum & Mean & Std.Deviation & N \\
\hline Predicted value & 342247.6875 & 916764.6875 & 504496.9653 & 194796.1311 & 19 \\
& -66797.08594 & 118512.8984 & .00000 & 63145.25088 & 19 \\
& -.833 & 2.116 & .000 & 1.000 & 19 \\
& -.997 & 1.769 & .000 & .943 & 19 \\
\hline
\end{tabular}

a. Dependent Variable:RGDP

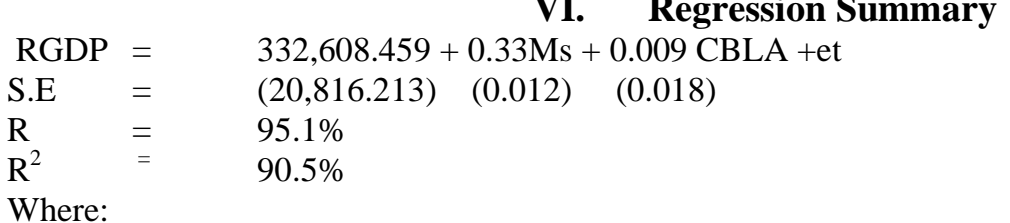

RGDP= Real GDP, Ms = money supply, CBLA= Commercial bank loans and Advances to the economy.

\section{Interpretation}

Our result shows that there is a significant strong multiple correction among RGDP, money supply and commercial banks loans and Advance $(\mathrm{R}=95.5 \%)$.

The coefficient of determination $\left(\mathrm{R}^{2}\right)$ reveals that $90.5 \%$ variations in RGDP were explained by our selected explanatory variables (money supply and commercial banks loans and Advances). From our Regression summary, CBN management of money supply has a statistical impact on the RGDP. This is shown on the value of money supply coefficient which has a value of 0.033 implying that a unit charge (100\% charge) in money supply attracted 0.033 unit charge $(3.3 \%)$ in RGDP with the year under view.

The presence of autocorrelation (Durbin water on= 0.299) shows omission of other explanatory variables that accounted variation in RGDP but were captured by our stochastic variable et. Our entire model is statistically significant and has forecasting power.

We therefore, reject our null hypothesis (Ho) and accept our Alternative Hypothesis (Hi) and concluded that effective money supply management by the central bank of Nigeria has impact positively on the general output of Nigerian economy.

In conclusion, we make inference that with the year under view CBN through effective management of money supply has achieved a desired price level that has propelled investors into committing more investment resources for expansion of output, the increase in output added value to the total RGDP and create more employment in the economy. 


\section{Reference}

[1]. Adesoye, A.B., Maku O.E. and Atanda A.A. (2012) Is Monetary policy a Growth Stimulant in Nigeria? A Vector Autoregression Approach. $\quad$ Munich Personal $\quad$ REPEC Archieve (MPRA) No. 35844.

[2]. Ajayi, I. (1999). Evolution and Functions of central Banks. CBN Economic and Financial Review. Vol. 37 No. 4

[3]. Central Bank of Nigeria (2009). Statistical Bulletin, Vol. 23. Abuja: Central bank Of Nigeria.

[4]. Central Bank of Nigeria (2010). Statistical Bulletin, Vol. 23. Abuja: Central bank Of Nigeria.

[5]. Central Bank of Nigeria (2011). Annual Report and Statement of Accounts. Abuja: Central bank Of Nigeria.

[6]. Christiano, L.J., Martin E. and Charles L.E (2005). Nominal Rigidities and the Dynamic effects of a shock monetary policy. Journal of political Economy 113(1).

[7]. Economic Times Election (2014). Times internet Limited, "Definition of Monetary Policy.

[8]. Epstein G. and Heintz J. (2006). Monetary Policy and Financial Sector Reform for Employment creation and employment Reduction in Ghana. Political Economy Research institute, university of Massachusetts, Working Paper.

[9]. Familoni, K.A, (1989). Development of macroeconomic policy. Nigeria: Lagos. Concept Publications.

[10]. Fasanya, I.O.,Onakoya, A.B and Agboluaje, M.A. (2013).Does Monetary Policy Influence Economic Growth in Nigeria? Asian Economic and Financial Review, 3(5)

[11]. Folawewo, A and Osinubi, T. (2006). Monetary policy andmacroeconomic instability in Nigeria: A Rational ExpectationApproach. Journal of Social Science,

[12]. Fasanaya ,I.O, Onakoya ,A.B.O. and Agboluaje, M.A. (2013). Monetary policy and macroeconomic instability in Nigeria: A Rational expectation Approach. Journal of Social Sciences. Vol. 12, No. 2

[13]. Monetary and Exchange Rate Policy (2010). Handbook of Development Economics. Elsevier.

[14]. Monetary Policy (2006). Federal Reserve Board. Jan 3.

[15]. Nneka, C.A. (2012). Investigating the Performance of Monetary Policy on Manufacturing Sector in Nigeria: 1980-2009.Arabian Journal of Business and Management Review (OMAN Chapter), 2(1).

[16]. Okwu, A.T., Obiakor, R.T., Falaiye, O.B and Owolabi S.A. (2011). Empirical Analysis of the effects of monetary policy innovations on stabilization of commodity prices in Nigeria. European Journal of Finance andAdministrative Science. Issue 32.

[17]. Sanusi, J. (2002). Central Bank and the macroeconomic environment in Nigeria'.Being a Lecture delivered to participants of the senior executive course No. 24 of the national Institute for policy and strategic studies (NIPSS), Kuru on 19th august

[18]. Soludo, C. (2001). Debt, Poverty and Inequality: Towards an exit strategy for Nigeria and Africa. Proceeding, international Conference on Sustainable Debt strategy. Abuja: Nigeria.

[19]. Uhlig, J.B (2005). What are the effects of monetary policy on output? Result from an Agnostic identification procedure. Journal of Monetary Economics 52(2).

[20]. Woodford, M. (2013). Interest and price. Princeton: Princeton University press www.investopedia.com 